Short Communication http://ajol.info/index.php/ijbcs http://indexmedicus.afro.who.int

\title{
Protein profile of breeding discrepancies of African catfish Clarias gariepinus in aquaculture practices
}

\author{
T. Agbebi OLUBUNMI*, G. Marcus IMOGIE and Sofolabi SHOFELA \\ Department of Aquaculture and Fisheries Management, Federal University of Agriculture, \\ PMB 2240, Abeokuta, Ogun State, Nigeria. \\ *Corresponding author; E-mail: agbebi20@yahoo.com; Tel: +2348-037045878
}

\begin{abstract}
The protein analysis focused on sarcoplasmic muscle of protein constituents to improve heterogenous growth of C. gariepinus. Ninety juveniles were graded and selected for the top $10 \%$, medium $10 \%$ and bottom $10 \%$ fish which represented fast, moderate and slow growing groups. The protein sample extracts were prepared by homogenizing $150 \mathrm{mg}$ of fish muscle and electrophoretic run in Sodium Dodecyl Sulphate (SDS) polyacrylamide gel. Eleven bands were found in large fish, eight bands in the medium fish and seven bands were detected in the small fish class. The $2^{\text {nd }}$ to $5^{\text {th }}$ protein band having molecular weight (MW) ranging from 116,200 to $70 \mathrm{KDa}$ was detected across all fish class sizes. The $6^{\text {th }}$ and $7^{\text {th }}$ band present in the large fish sample class but absent in the other two classes, having MW $54.52 \mathrm{KDa}$ and 54.21 KDa respectively are assigned to Desmin protein. The 1st band was the heaviest (MW 118,600 KDa) band only found in the large sized fish. The results revealed that $1^{\text {st }} 6^{\text {th }}$ and $7^{\text {th }}$ bands are the distinguishing protein bands and these proteins have contributed to the heterozygosity nature of the large size class which are most suitable for broodstock selection for future artificial propagation practices.
\end{abstract}

(C) 2015 International Formulae Group. All rights reserved.

Keywords: Electrophoresis, molecular weight, broodstock, sarcoplasmic, heterozygosity.

\section{INTRODUCTION}

Clarias species is the most cultured fish species in the Nigerian Aquaculture industry today. The species dominating over $85 \%$ of the industry is plagued with the problem of unhealthy heterogeneous growth surprisingly from the early days of life (FAO, 2005). Hatchery experts have come up with grading systems for fingerlings resulting from differential growth patterns. Fish sizes obtained in breeding exercise are majorly grouped into three classes: large, medium and small classes. Consequently, aquaculture expansion has been in slow process as private sector fish farmers face constraints such as supply of quality fish seed (FAO, 2003). Discrepancies at the early stage of their life results to cannibalism amongst the species, with resultant effect in population decline, economic disadvantage and decreased profitability, other effects are reduction in production indices such as growth, feed conversion efficiency and adaptability (Nwafili and Gao, 2007). The desire of fish 
farmers is to produce table sized fish within the shortest possible time. Consequences of this simple problem have led to the fold up of many fish farms and the widening of the demand-supply gap. Agbebi et al. (2003) and Ataguba et al. (2010) suggested that efforts have to be geared towards producing more homogenous number of large sized class fish seeds which is profitable for grow out farmers.

This study was aimed at determining the protein profiles of each of these three classes of fish to improve on heterogeneous growth of the species.

\section{MATERIALS AND METHODS}

\section{Broodstock selection}

The broodstocks of $C$. gariepinus of known breeding records used for the experiment were obtained from Hepa Fish Farm, Asero, Abeokuta, Nigeria (Lat. $7^{0} 25^{\prime \prime} 3.68 \mathrm{~N}$ to $7^{0} 4^{\prime} 13.06 \mathrm{~N} \mathrm{~N}$ and Long $3^{0} 0^{\prime} 9.20$ "E to Long $3^{0} 24$ '10.92 "E). Gravid females of C. gariepinus were selected based on their swollen reddish genital papilla and a welldistended, swollen soft abdomen that oozed out eggs when gently pressed. Sexually matured males of $C$. gariepinus were selected based on reddish pointed and vascularised urogenital papillae. After selection, the broodstocks were immediately transferred in plastic troughs and taken into the hatchery.

\section{Artificial fertilisation}

Hypophysation of the specimens were carried out in the hatchery of Hepa Fish Farm, Asero, Abeokuta where hatchlings were reared. The selected broodstocks of $C$. gariepinus were kept separately in hatchery for two days without feeding to empty the alimentary tract at the time of stripping. Oocyte maturation and ovulation in the female broodstocks were induced by a single intramuscular injection of Ovaprim (SYNDEL, Canada) at a dosage of $0.5 \mathrm{ml} / \mathrm{kg}$ live weight as described by Viveen et al.
(1985) and then left for 10-17 hours latency period to ensure high hatching rate and low proportion of deformed larvae.

The body of the female broodstock was carefully dried with a clean towel and tightly held at head and tail ends while the eggs were hand-stripped by pressing their abdomen into clean and dry bowl. The eggs were fertilized with milt obtained from lacerated testes by using feather to spread the mixture evenly for one min. The fertilized eggs from each mating combination were spread out in single layer on the screen nets (mesh size of $1 \mathrm{~mm}$ ) placed in the hatching tanks at $27^{\circ} \mathrm{C}$ to $28^{\circ} \mathrm{C}$.

Fertilized eggs were incubated separately in aerated water tanks with continuous flow through system. After eggs hatched, the larvae were allowed to absorb their yolks for three days, after which they were fed and reared for 8 weeks.

\section{Selection of fishes into their different sizes}

The fingerlings were selected into different sizes after breeding and feeding with the same feed type (Robinson et al., 1998). The fingerlings were separated after 4 weeks of rearing using their length and weight and were reared for 8 weeks. A transparent ruler was used to measure the length while weight was measured using a digital sensitive scale.

Fingerlings fish samples (comprising three samples from each fish sizes) were transported live in well open plastic rubber bowls to the Biotechnology Laboratory Centre of the Federal University of Agriculture, Abeokuta.

\section{Muscle sample collection}

Sarcoplasmic extracts were prepared by homogenizing $150 \mathrm{mg}$ of muscle with the aid of a mortar and pestle (on ice) in 1.5 $\mathrm{ml}$ of rigor buffer containing10 $\mathrm{mM}$ Trismeleates, $60 \mathrm{mM} \mathrm{KCl,} 5 \mathrm{mM} \mathrm{MgCl} 2,1$ 
nM EDTA (Zapata et al., 2008). The extracts were centrifuged in a tube at 10,000 $\mathrm{g}$ for $5 \mathrm{~min}$ at $4{ }^{\circ} \mathrm{C}$. Supernatant (sacroplasmic extract) was transferred to new microcentrifuge tubes. $500 \mu \mathrm{l}$ of the sarcoplasmic fraction was then transferred to new tubes and $1 \mathrm{ml}$ of urea/thiourea buffer was added to each tubes. All samples were mixed on vortex machine and incubated at room temperature for approximately 1 hour and then stored in a refrigerator at $-20{ }^{\circ} \mathrm{C}$ for analysis.

\section{Sample preparation for SDS-PAGE analysis and gel staining}

Protein fractions were centrifuged for 5 minutes at $10,000 \times \mathrm{g}$ at room temperature prior to the electrophoretic analysis. Samples were loaded into $1 \mathrm{~cm} \mathrm{x} 12 \mathrm{~cm} \mathrm{x} 14 \mathrm{~cm}$ into $12.5 \%$ polyacrylamide gel with $3 \%$ stacking gel. First, gel capillary chamber was loaded with a broad range molecular weight standard (BioRad Laboratories, Hercules, CA). Proteins were separated by applying constant voltage of 300 Volts for 2 hours 30 minutes until the dye front reached the bottom of the gel. After electrophoretic separation, gels were stained overnight with gentle agitation on an orbital shaker. Staining buffer contains $(400 \mathrm{ml}$ methanol, $50 \mathrm{ml}$ glacial ethanoic acid and Coomassie Brilliant Blue G250) and subsequently destained with $10 \%$ ethanoic acid.

Image was visually analysed into the three class sizes from the $12.5 \%$ SDS PAGE raw image produced.

\section{RESULTS}

In Figure 1, the electrophoregram resolved eleven bands found in large fish, eight bands in the medium fish and six bands were detected in the small fish class. The $2^{\text {nd }}$ to $5^{\text {th }}$ protein band having molecular weight (MW) ranging from 116,200 to $70 \mathrm{KDa}$ was detected across all fish class sizes. Large sized and medium sized class observed a common band of MW $52 \mathrm{KDa}$ which is absent in small class. The distinguishing bands $6^{\text {th }}$ and $7^{\text {th }}$ present in the large fish sample class but absent in the other two classes, having MW $\quad 54.52 \mathrm{KDa}$ and $54.21 \mathrm{KDa}$ respectively. The $1^{\text {st }}$ band was the heaviest (MW 118,600 KDa) band only found in the large sized fish class but absent in the other fish classes.

In Table 1 a total number of thirteen protein bands were revealed by the protein electrophoregram. The Bio range standard was calibrated having molecular weight (MW) of $240,000 \mathrm{KDa}$ to the minimum of 21,200 KDa.

No band was resolved for any of the class sizes between the highest MW ranges of $240,000 \mathrm{KDa}$ and 230,000 KDa. The first largest protein band resolved was found in large size class with MW 118,600 KDa followed by $116,600 \mathrm{KDa}$. The $\mathrm{MW}$ of $116,600 \mathrm{KDa}$ ran across the three class sizes followed by MWs of $110,000 \mathrm{KDa}, 95,000$ $\mathrm{KDa}$ and 70,000 KDa in the three class sizes.

The protein band size with MW of $66,200 \mathrm{KDa}$ was resolved only in the large class size followed by MWs of 54,420 KDa and no band was resolved for medium and small class sizes. This was followed by MWs $52,210 \mathrm{KDa}$ in the large and medium category, at the eleventh reference number in Table 1, MW of 45,000 KDa was resolved for large, medium and small size classes. The lowest band in the bio-range standard 21,200 KDa was also resolved across the three class sizes. 


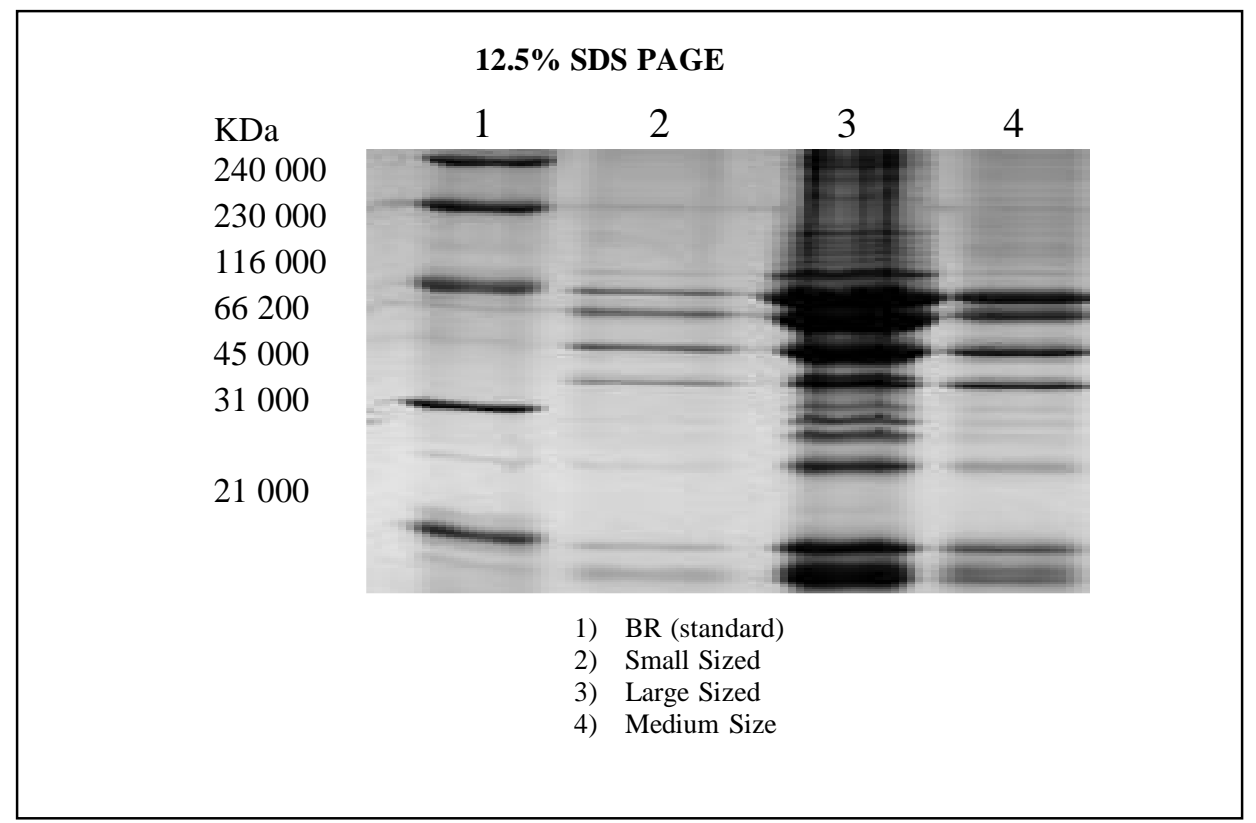

Figure 1: Raw image of $12.5 \%$ SDS Whole Muscle Protein of C. gariepinus.

Table 1: Molecular weights of bands detected for Calibrated Image of $12.5 \%$ SDS Sarcoplasmic Muscle Protein of C. gariepinus,

\begin{tabular}{lcccc}
\hline $\begin{array}{l}\text { Ref } \\
\text { Band }\end{array}$ & Bio Range & Large & Medium & Small \\
\hline 1 & 240,000 & - & - & - \\
2 & 230,000 & - & - & - \\
3 & - & 118,600 & - & - \\
4 & 116,600 & 116,600 & 116,600 & 116,600 \\
5 & - & 110,000 & 110,000 & 110,000 \\
6 & & 95,000 & 95,000 & 95,000 \\
7 & & 70,000 & 70,000 & 70,000 \\
8 & 66,200 & 66,200 & - & - \\
9 & & 54.420 & - & - \\
10 & & 54.210 & 54,210 & - \\
11 & 45,000 & 45,000 & 45,000 & 45,000 \\
12 & & 40,000 & 40,000 & 40,000 \\
13 & 31,000 & - & - & - \\
14 & 21,200 & 21,200 & 21,200 & 21,200 \\
\hline
\end{tabular}




\section{DISCUSSION}

The ratio of large sized to medium sized and small sized fingerlings obtained in this research show a remarkable need for more research and development of large sized fingerlings. Electrophoresis separation by SDS-PAGE muscle sarcoplasmic proteins revealed protein variations among same species of fish. This corroborated the findings of Agbebi et al. (2013) where the protein fingerprint of fish size variation in yellow perch was identified. Protein variation among the same batch of fish species connote that there are proteomic differences amongst them therefore amino acid improvement in their diets could be the possible solution. The problem resulting from unwholesome hatchery practice of mixed broodstock crossing should be addressed (Nwafili and Gao, 2007) so that aquaculture practitioners exploiting the fertility of the intraspecific $\mathrm{F}_{1}$ and $\mathrm{F}_{2}$ Clarias (gariepinus and anguilaris) hybrids as breeders for further propagation.

This result has revealed that $1^{\text {st }}, 6^{\text {th }}$ and $7^{\text {th }}$ bands were the distinguishing protein bands. The first band was the heaviest MW (118,600 KDa) band and was identified as myosin breakdown protein product, the sixth and the seventh bands with MW of $54 \mathrm{KDa}$ were assigned as Desmin protein (Albert et al., 1994) which helps in muscle contraction, plays significant roles in maintenance and structural built up muscles. The $2^{\text {nd }}$ to $5^{\text {th }}$ bands of Molecular weight ranging from 116,200 to $70 \mathrm{KDa}$ correspond to protein Nebulin and Actin. The combinations of these proteins have contributed to the heterozygosity nature of the large size class which are most suitable for broodstock selection for future artificial propagation practices.

\section{Conclusion}

This work has been able to prove that the challenge of size variation in fish breeding or artificial propagation of the same species fed with the same feed and at the same time can be tackled by aquaculturist using the right brooders. The protein profile of the fish in this study suggests that the heterozygosity in large fish class might be as a result of the presence of the protein Desmin which is the influential protein in this fish class. This study also suggests that the higher the band, the greater the heterozygosity in fish sizes as the large fish size had the highest number of bands compared to the medium and small fish sizes. Desmin play a critical role in the maintenance of structural and mechanical integrity of the contractile apparatus in the muscle tissues. This large fish should be jealously guided for future use as it will be excellent brooders for breeding exercise although the medium class can also be used.

This study displaces the hypothesis that discrepancies in fish class size is as a result of environmental or management problems, but could be concluded as a result of the protein profiles of the various class sizes.

\section{ACKNOWLEDEGMENTS}

We wish to acknowledge the manager and staff of Hepa Fish Farm for taking their time to source for good catfish of known age to carry out the propagation study. Our appreciation also goes to Director and staff of Biotechnology Laboratory Centre of the Federal University of Agriculture, Abeokuta for their timely assistance during the proteomic research study.

\section{COMPETING INTERESTS}

Authors have declared that no competing interests exist.

\section{REFERENCES}

Agbebi OT, Wick MP, Popovski ZT. 2013. Evaluation of three protein fractions in yellow fish perch species, perca flavescens using two extraction buffers: Trichloroacetic Acid and Rigor Buffer. Ife Journal of Science, 15(2): $197-$ 208.

Alberts BD, Bray J, Lewis M, Raff K, Roberts JD. 1994. Molecular Biology of 
the Cell. Aquaculture, Culture of Clarias species, 63(1-4): 221-231.

Ataguba GA, Annune PA, Ogbe FG. 2010. Growth performance of two African catfishes Clarias gariepinus and Heterobranchus longifilis and their hybrids in plastic aquaria. Livestock Research for Rural Development, 22(30).

FAO. 2003. Opportunities for Aquaculture Development in Nigeria, FAO Aquaculture Newsletter. FAO: Rome; 39.

FAO. 2005. The State of World Fisheries and Aquaculture Report. FAO Fisheries and Aquaculture Department. Rome, 164 pp.

Nwafili SA, Gao T. 2007. Is the Dutch domesticated strain of Clarias gariepinus
(Burchell, 1822) a hybrid? African Journal of Biotechnology, 6(8): 10721076.

Viveen WJAR, Richter CJJ, Van Oordt PGWJ, Janssen JAL, Huisman EA, 1985. Practical manual for the culture of the African catfish (Clarias gariepinus). The Netherlands Ministry for Development Cooperation, Section for Research and Technology, EB the Hague: The Netherlands; 128.

Zapata I, Zerby HN, Wick M. 2009. Functional proteomic analysis predicts beef tenderness and the tenderness differential. J. Agric. Food Chem., 57: 4956-4963. 